\title{
Four Pack
}

National Cancer Institute

\section{Source}

National Cancer Institute. Four Pack. NCI Thesaurus. Code C78776.

A product containing four individual units. 